\title{
How these three schools in Indonesia could exceed the international average score in TIMSS 2015?
}

\author{
Fasiha Fatmawati ${ }^{1 *}$, Heri Retnawati ${ }^{2}$ \\ ${ }^{1}$ Department of Primary Education, Program Pascasarjana, Universitas Negeri Yogyakarta. \\ Jalan Colombo No. 1, Karangmalang, Yogyakarta 55281, Indonesia. \\ ${ }^{2}$ Department of Mathematics Education, Fakultas Matematika dan Ilmu Pengetahuan Alam, \\ Universitas Negeri Yogyakarta. Jalan Colombo No. 1, Karangmalang, Yogyakarta 55281, Indonesia. \\ * Corresponding Author. E-mail: fasiha0886pasca@student.uny.ac.id \\ Received: 23 July 2018; Revised: 17 September 2018; Accepted: 20 September 2018
}

\begin{abstract}
The achievement of students' mathematics learning is strongly influenced by how the learning process takes place in the classroom. But, that is not the only factor that could affect learning achievement. This research aimed to describe the advantages of learning in three schools in Indonesia with highest score in TIMSS 2015 which exceed international standard score. Participants in this case study research were 3 teachers and 3 students from the three elementary schools, that are SD N Gunungsaren, SD N Kentungan, and SD N Semanu III in Yogyakarta Province, Indonesia. Data triangulation had been conducted to test the validity of data collected by observation, in-depth interviews, and documentation. Data analysis was carried out qualitatively by adapting the techniques developed by Miles, Huberman, and Saldana which consisted of condensation data, data presentation, and conclusions. From the result, it can be concluded that the process of mathematics learning in the three schools implemented by involving students actively in learning activities. Each school had advantage that support the implementation of learning activities. SD N Semanu III supported by the completeness of the facilities in schools in the form of projectors that teachers use well in learning. The success of student learning in SD N Kentungan supported by parents' involvement which providing support and facilitate children's learning. Meanwhile, the success of learning in SD N Gunungsaren supported by teacher creativity factors developed through teacher training activities that applied in classroom.
\end{abstract}

Keywords: mathematics learning, school facilities, parents' involvement, teacher creativity

How to Cite: Fatmawati, F., \& Retnawati, H. (2018). How these three schools in Indonesia could exceed the international average score in TIMSS 2015?. Pythagoras: Jurnal Pendidikan Matematika, 13(1), 1-9. doi:http://dx.doi.org/10.21831/pg.v13i1.20486

http://dx.doi.org/10.21831/pg.v13i1.20486

\section{INTRODUCTION}

Mathematics needs to be learned because it is very useful when applied in everyday life. Mathematics not only deals with counting numbers, but also contains conceptual and procedural knowledge that examines how to understand and do things (Riedesel, Schwartz, \& Clements, 1997). Lawrence (Chambers, 2008) states that what is learned in mathematics can be applied in art, science, finance, health, even in spare time. Skills gained by students from learning mathematics will be very useful to solve the daily problem or later in life. When students study mathematics in a context but can not apply it in different contexts, mathematics will not be of much use (Haylock \& Thangata, 2007). In order to make mathematics useful, students must be able to understand it first then apply it in context.

Getting students to understand and to be able to apply mathematics subject matter becomes a challenge for teachers because students assume that mathematics is a difficult subject. Difficulties of students in absorbing mathematics lessons reached $88.57 \%$ in comparative and scale; distance, time, and speed; mixed operation; as well as measurement of area (Retnawati, Kartowagiran, Hadi, \& Hidayati, 2011). This can be one of the reasons why the students' mathematics scores in Indonesia are still low, judged from the average outcome of national exam. The students' mathematics skills in 
Indonesia at the international level can also be seen from the TIMSS (Trend in International Mathematics and Science Study) results. From the latest TIMMS results in 2015, the mathematics achievement of fourth grades students in Indonesia gained an average score of 397, which is still far below the international average score of 500. The score puts Indonesia at the rank of 45 out of 50 participating countries. From the results of TIMSS 2015 also known that Indonesian students' mathematics skills at the stage of knowing is quite high up to $60 \%$ and decreased at a higher stage. These results illustrate that Indonesian students' mathematics achievement must continue to be improved.

There are five elementary schools in Yogyakarta Province, Indonesia that participated in TIMSS 2015. From these five schools, three schools gained high scores in numeracy and mathematics. The scores exceed the Indonesian average score, even international average scores. Here are the score results of the three schools.

Table 1. TIMSS 2015 Score Results of Three Schools in Indonesia

\begin{tabular}{lcc}
\hline \multicolumn{1}{c}{ School } & Numeracy Score & Math. Score \\
\hline SD N Gunungsaren & 557 & 524 \\
SD N Kentungan & 533 & 505 \\
SD N Semanu III & 513 & 499 \\
\hline
\end{tabular}

The achievement scores of these three schools can indicate that the students' mathematics ability is beyond average. The high mathematics achievement is certainly obtained from the results of learning that is implemented effectively. The implementation of effective mathematics learning depends on the teacher's knowledge and use of learning material, the attention given by the teacher in working with the students, and the involvement of students with mathematical tasks (Kanold, Briars, \& Fennel, 2012).

Although mathematics learning that takes place in the classroom is strongly influenced by the teacher, teachers are not the only influential factor in learning. National Research Council (2001) mentioned that the teaching of mathematics can be defined as product of the instructions among the teacher, the students, and the mathematics. It means that the effectivity of mathematics learning involves the components: teacher, students, and material. Sanjaya (2013) also mentioned that there are some factors could affect learning activities such as teachers, students, facilities and infrastructure, and the environment. Especially for elementary students, parental involvement in children's education will be very influential. Kanold, Briars, and Fennel (2012, p.116) stated, "Families are their children's first teachers and are in prime position to have an important influence on their children's academic development." Parents can influence their children's achievement through the value they communicate about education, effort, persistence, and responsibility. If the family, especially the parents cares about children's learning, parents will support to create a conducive situation at home for children to learn and facilitate the learning. This will make the child become motivated to learn and achieve better performance.

The three schools of research sites are not the most excellent schools in Indonesia, but in TIMSS 2015, these schools were able to achieve high scores beyond the international average. It is certainly interesting to investigate how teachers conduct mathematics learning activities to improve students' mathematical abilities, and whether there are factors that do support learning activities in these three schools. Through this research also, it is expected that the results obtained can contribute in improving the quality of mathematics learning.

\section{METHOD}

The research was a case study research. This research tried to describe the advantage of mathematics learning in three schools in Indonesia obtained high scores in numeracy and mathematical score in TIMSS 2015.

The participants of this research were three teachers (T1, T2, T3) and three students (S1, S2, S3) from three elementary schools in Yogyakarta Province, Indonesia that became participants in TIMSS 2015. The schools were chosen based on the result of TIMSS 2015 in numeracy and mathematical score that exceed the international average. These three schools are SD N Gunungsaren in Bantul, SD N Kentungan in Sleman, and SD N Semanu III in Gunungkidul. Each school is located in different district in Yogyakarta Province, Indonesia.

Data for this research was collected using observation, in-depth interviews, and documentation. Observation was used to describe the mathematics learning conducted at school, how the teacher design learning and assessment, and how the students interact. The observation was followed by in-depth interview to seek a deeper understanding about the implementation of learning. Documentation was used to support 
data collection about lesson plan made by teachers, students' task, and how teachers did the assessment.

Data obtained from the field were analyzed by adapting qualitative data analysis techniques developed by Miles, Huberman, and Saldana (2014). Data analysis techniques include data condensation, data presentation, and conclusions.

\section{FINDINGS AND DISCUSSION}

\section{Result}

From the observation, interview, and document analysis, the research result is then classified based on research location. The followings are the result of each school.

SD N Semanu III in Gunungkidul District, Yogyakarta Province, Indonesia

According to the learning standard, the learning process performed in Indonesian schools consists of three activities: opening, main, and closing activities. In SD N Semanu III, before the learning, the class is usually given the 'literacy hour' by reading non-material books or mathematics practices. In the opening activities, teacher and students run question and answer activity, and apperception presentation. The next activity is the main activity. Within the main activity, teacher has left conventional teaching methods, namely lecturing. One of factual example is teacher using discovery learning method when teaching prime numbers. Teacher design the learning activity, in which students are encouraged to discover, and understand what prime numbers are. Besides, the teacher also uses cooperative learning. This method gives the students have and use the chances to independently study and arrange their own understanding about particular subject, instead of being dependent to teacher's lecturing.

Student's involvement obviously occurred and is well observed. The teacher makes effort to involve students in every learning process in order to promote students' activeness in learning. Students also compete to answer any question given. This method has been applied daily, as seen from students' courage of getting involved. Also, the students seem to show zero fear of making mistake in answering the questions.

In mathematics class, teacher gives assignments for students, both for individual and collective. The assignments consist of routine assignment and non-routine assignment, which are in the form of essay assignment. The routine assignment is designed to sharpen students' basic fact skills and procedural skills. While, the nonroutine assignment functions to increase students' problem-solving skills. The following is one of the examples of essay assignment.

"Uncle Ben has a small field. The field is 10 $\mathrm{m}$ by $8 \mathrm{~m}$. Uncle Ben wants to plant banana trees around the field. If one banana tree will be planted in every $2 \mathrm{~m}$, then how many banana trees will he need?"

Other mathematical skills are also stimulated by the teacher. Creative thinking skill is stimulated in the classroom by giving each students independence to solve the assignment in any way each student feels comfortable. Critical thinking and reasoning skills are activated by asking them to back-up their answer for the assignment. For example, teacher asks 'Is ' 4 ' a prime number? Why? Why not?"

Class is closed by performing assessment. Teacher performs the assessment by giving written or spoken quiz to students about the materials. Teacher also score the assignment in both numerical score and feedback. Teacher marks the parts, which students need to improve. The feedback is designed to show the students of their level of understanding. Beside cognitive assignment, students' attitude also assessed by daily observation, skill assessment, and students' work assessment.

During the research, researcher found that there are several supporting factors of the learning process in SD N Semanu III. Compared to the other two schools, this school has more complete facilities. This school shows an appropriate way of optimizing school facilities for classroom learning, particularly with LCD projector. The school is well-equipped with LCD projector in every classroom, to ease teacher prepare the presentation. Teachers of this school require a very little effort to use the LCD projector.

The teachers themselves believe that LCD projectors have been very helpful in presenting classroom materials, especially subjects with abstract concepts. The $4^{\text {th }}$-grade students agree that LCD projector have helped them in understanding the materials. The teacher stated as follows:

"We have been using laptop and LCD projector for quite some time. It has become a primary need in teaching-learning process. Actually, it feels a little weird for me to teach 
without them (laptop and LCD projector). The students love it. And, internet has been very helpful as a source of materials. Plus, the school is also well equipped with Wi-fi service." (T1)

The teacher's statement proves that school's effort in providing $W i-f i$ has been very helpful for teachers to prepare their teaching presentation, and eventually lead to the better teaching-learning process. LCD projector helps teachers to present their subjects, and keep students entertained, as well.

SD N Kentungan in Sleman District, Yogyakarta Province, Indonesia

The learning process in SD N Kentungan is usually opened by teacher encouraging students to clap hands. The clapping is aimed to encourage students' mood and be more focused. After the opening activity is done, teacher starts presenting apperception, explaining the overall materials and today's goal of achievement. During the learning process, the teacher performs a student-centered learning process. Students are encouraged to actively get involved in the process. For example, during learning the material of angle, the teacher uses the contextual learning method, by using concrete objects around. Teachers encourage students to explore the space, take the objects they are interested to, and finally, measure the angles of the objects. Students clearly seem to be active in discovering the objects, such as clocks, desks, maps, windows, and etc.

In addition to employing contextual learning method, the teacher also uses cooperative learning method. By these cooperative learning methods, students are encouraged to be cooperative especially with their teammates. These learning method emphases the student-centered point of view, instead of teacher-centered point of view. The teacher commented:

"The plan is to give students group assignment, and group discussion so students will actively get involved, instead of the oldfashioned lecturing method. We have to ensure that any model employed in the classroom should encourage students' involvement." (T2).

Similar to SD N Semanu III, the teacher optimizes the usage of assignment. The teacher employs both routine assignment and non-routine assignment. To increase students' basic logic skills, such as multiplication, the teacher uses listening assignment. While to increase students' problem-solving skills, the teacher employs essay assignments.

During the closing activities, the teacher performs an evaluation. The assessment performed by the teacher of SD N Kentungan is comparably similar to that of SD N Semanu III teacher. The teacher performs assessment on attitude, knowledge, and skill. The teacher also gives scores, and feedback. The feedback is in the forms of numerical score, tick (v) marks, cross (x) marks, and little notes. Motivational speaking is also embedded. Teacher usually motivates students by saying

"Okay students, learning is better than getting a score. Those who get satisfying score, please be humble and grateful, and strive to stick up. Those who still feel dissatisfied with the score, please don't get discouraged, as there are chances next times." (T2).

Generally speaking, the learning process of SD N Semanu and SD N Kentungan are carried with little difference. Both teachers make efforts to get the students involved. However, the teacher of SD N Semanu have better time optimizing learning facilities, such as LCD projector, as SD N Kentungan has not yet installed LCD Projector in each classroom.

However, another factor seems to have a role in students' learning success, which is parents' involvement. Parents of SD N Kentungan seem to show high level of care of their children education. Several students admit that their parents help them in completing their homework. It is also common for parents to even ask teachers about their children's assignment. Furthermore, parents also encourage their children to love literature. Some students admitted that they love reading and owns a number of book collection $\mathrm{A}$ student reported,

"My dad gave me four books for my birthday present, so I will read a lot." (S1)

In addition to helping children with homework and encouraging book-loving habit, parents also show their involvement by providing internet service at home. The same student, also reported that internet is a great help in completing his/her homework. Other student seems to agree on this point.

Enrolling children in learning course is also a factual example of parents' effort to ensure children's learning. Several parents enroll their 
children in either classical learning course, or private learning course. Students admitted,

"I have a private course at home" (S2).

"I joined two learning courses, Mathematics and English." (S3).

From teacher point of view, the teacher intentionally designs a homework encouraging parents' involvement. The teacher intentionally asks students to ask help from their parents in using the internet to complete their homework. Teacher's effort to increase the parents' involvement can also be observed from the existence of WhatsApp group of teacher and parents. This social media functions to share any school information and to encourage parents' involvement.

SD N Gunungsaren in Bantul District, Yogyakarta Province, Indonesia

Similar to SD N Semanu III, classes in SD N Gunungsaren starts with 'literacy hour'. This specific agenda is filled with reading nonmaterial books, or mathematics quiz. The teacher bridges the 'literacy hour' and the learning process by singing and/ice breaking. Only after that, the teacher presents the materials and the goals of today's class.

Much like to the other two previous schools, most of the learning processes of SDN Gunungsaren are performed under cooperativelearning method. As observed, the teacher almost always designs the learning process in a group discussion method, for examples in data analysis, angle, and thematic subjects. In every class, the teacher always involves students. One of the involvement examples is mentioning some objects related to the materials. Besides, students are always welcome and encouraged to optimize learning media available.

To increase students' mathematical skill, the teacher of SD $\mathrm{N}$ Gunungsaren provides several assignments, both routine and nonroutine. The assignment type is similar to the previous two schools', as the teachers use the same book as source. Yet, the material presentation is different, to meet the need of each class condition.

For the learning assessment, the teacher of SD N Gunungsaren performs 3-aspect assessment: knowledge, attitude, and skill, similar to the teachers of SD N Semanu III and SD N Kentungan. However, there is a difference. The teacher of SD N Gunungsaren doesn't only use observation technique, but also self-assessment technique. This technique employs a simple attitude scale to assess one's own attitude, such as honesty, discipline, tolerance, cooperativeness, and religiousness. While to asses students' skill, the teacher employs product assessment as well as peer-assessment. Student presentation plays role as sources of this peer-assessment technique. The teacher also gives feedback and/or motivation to the students. The motivation is given in written note, or in verbal manner, such as by speech, or even singing performance. One example of written feedback is "Keep it up, and focus more in understanding the questions".

In terms of learning facilities, SD $\mathrm{N}$ Gunungsaren falls behind SD N Semanu III. While parents' involvement in students' learning seems to be on the lower side. However, this school gained the highest score of TIMSS 2015. In this very case, the most influential factor of successful learning of this school is teacher's creativity, particularly in managing the class.

As stated above, the teacher employs ice breaking activity, rather heavily. Researcher finds that the teacher stops the class whenever students seem to be bored. The teacher usually asks them to stand up and sing. On one occasion, the teacher stated: "You seem bored. Let's just sing first." Also, the teacher makes use of 'Concentration Clap' to avoid boredom. This singing performance is aimed to attract students' attention, to restore concentration, and even to mentally encourage students. Furthermore, the singing performance is embedded in learning process as a game to run the group discussion.

As an effort to improve teachers' competence in teaching, teachers are usually sent to join any seminars and trainings. Those activities are fully supported by school and principal. During an interview, a teacher happens to mention about the role of a particular training center for teachers. Evidently, this particular training center has influenced teacher's class management. The teacher stated that:

"I was the first one appointed by school to join the training. There were some teachers who joined it independently. During the training, we were taught how to manage the class, including fun class activities, such as singing performance" (T3).

Thus, highlight the very positive impact of the trainings to the teacher of $4^{\text {th }}$ grader class of SD N Gunungsaren, in terms of class management, fun class activity, up to creativity. The teacher's creativity has also been appreciated by 
Education Department, with formal certificate, which eventually, encourage the teacher to continue his/her development.

Teacher's creativity is also proved by his/her effort to create learning media. The teacher stated,

"I do create my own learning media: mathematics, and science. I even create waterpowered rocket. I develop that idea from the book. And, I did win a water-powered rocket competition in my scout competition" (T3).

"I am in the process of writing. I hope I can publish it, someday." (T3)

\section{Discussion}

How teachers conduct the learning process does have a great influence on students. As stated in the research result, the learning processes in those three schools are not teacher-centered, rather teacher-student-interactive. This kind of learning process ensures that students get the points of the materials, without overly limiting their participation. Ganyaupfu (2013) theorized that interactive learning process between teacher and student is the most effective one. Gurney (2007) stated that effective teacher-student interaction encourage a stimulating situation for students to learn well.

There are many innovative learning models that can be used by teachers in the learning process. Some of these learning models are problem based learning (Djidu \& Jailani, 2017, 2018; Jailani, Sugiman, \& Apino, 2017), creative problem solving (Apino \& Retnawati, 2017), and project based learning (Anazifa \& Djukri, 2017) enhances students' thinking skills by presenting real problems. In addition, there are other learning models such as CTL (Laili, 2016), and inquiry learning (Widiastuti \& Santosa, 2014) that have a positive effect on students' achievement, curiosity, and reasoning skills.In the three schools where the study was conducted, the teachers use teaching method such as cooperative learning, CTL, or inquiry learning.

By those teaching method, teachers give the students opportunity to learn more. Teachers provide scaffolding to help students master new skills in mathematics. Teachers will give assisstant to students before they can work by their own. This support given by teachers is believed can affect students' self-concept that directly or indirectly increasing mathematics achievement (Murdiyani, 2013).

Innovative learning method is evidently proved to improve students' achievement, compared to traditional method (Khursid \& Anshari, 2012). Interactive learning process functions to avoid classroom boredom. While, various fun learning activities function as a key of effective learning process (Gurney, 2007).

By understanding that the learning process doesn't only occur inside the classroom, wider learning condition plays roles in determining students' learning success, as well. Based on the research, the three schools in which the research are performed show different supportive factors of students' learning process. Those are 1) learning facilities, 2) parents involvement, 3) and teacher's creativity.

SD N Semanu III seems to be the most wellequipped among the three schools. The facilities, particularly LCD projector, enable the teacher to perform the learning process very well. Each classroom is installed with LCD projector. While, learning facilities is a significant factor of students' learning and academic achievement (Singh, Malik, Singh, 2016; Mushtaq \& Khan, 2012; Odeh, Oguche, \& Ivagher, 2015). The availability and the quality of the learning facility affect and improve students' achievement (Limon, 2016; Suleman \& Hussain, 2014).

Learning facilities must be provided by both schools and parents. Parents' involvement in children's learning, including their provision of facilities, is believed to have positive impact on children's learning success. Parents are an important influence on their children's learning (Hewitt \& Tarrant, 2015, p.26). Parents' involvement ranges from providing learning facilities at home, helping with homework, discussing children's learning with teacher, to participating in any school-parent activities.

SD N Kentungan seems to show the highest rate of parents' involvement. Statistically, parents of SD N Kentungan students belong to middle-upper economy class, which indirectly gives them opportunity to pay more attention to children's learning. This can be seen from their willingness to provide books and internet service, and to enroll their children in learning centers. Altschul (2011) theorized that parents' financial investment on children's education significantly brings positive achievement of children's learning achievement. Parents' involvement in SD N Kentungan seems to be more apparent than the other two schools. Moreover, the teacher supports parents' involvement by designing parent's-involved homework. This seems to be effective strategy in encouraging parents' 
involvement, as theorized by Thompson, Gillis, Fairman, \& Mason (2014). He theorized that parents' involvement is directly proportional to children's learning achievement.

Students of SD N Kentungan admit that parents are helpful in lending hands in homework. Parents also seems eager to check their children's assignment to both their own children and the teacher. Numerous researches have shown there is a significant and positive influence on parents' involvement to children's intelligence and achievement (Topor, Keane, Shelton, Calkins 2010; Jethro \& Aina, 2012). While Harris \& Goodall (2008) and Bailey, Silvern, Brabham, Ross. (2008) found that parents' involvement at home is significantly more influential than parents' involvement at school. Children whose parents are interactive to themselves and their schools show higher involvement and academic achievement (Mo \& Singh, 2008).

However, teachers poses the most influential role in students' learning process. Teacher is a specific profession with particular set of skills and competence. Teachers are expected and obliged to have not only wide knowledge, but also strong character and personality as a positive role model. Osguthorpe (2008) theorized that

"If there is a truism in education, it is that good teaching requires a teacher to be knowledgeable in content, skilled in method, and virtuous in disposition and character".

Olaleye (2011) believed that there is a significant correlation between teacher's characteristics and students' academic achievement. Gender, teaching experience, qualification, interpersonal to students, and knowledge in content affect students' academic achievement (Ibe et al., 2016). Teachers are obliged to perform a continuous self-development to withstand and overcome various challenges in education. Given every teacher is doing so, Indonesian education will achieve a great success in giving birth to talented and successful youth. Unfortunately, there are still many teachers in other schools who have difficulty in planning and implementing innovative learning models that can help students develop competencies in solving problems related to the real world (Retnawati, Djidu, Kartianom, Apino, \& Anazifa, 2018)

According to the research, the most influential factor of teachers' characteristics development in SD N Gunungsaren is the teacher training program. The creativity in learning process of SD N Gunungsaren teachers poses as the actual result of the stated teacher training program. The training program provides a great source of ideas, method applications, and techniques to be applied in their own classes. Baradaran, Khosravipour, Rafe, Moosavi, \& Roozbahani (2015) theorized that teacher training program boosts students' academic achievement. Similarly, Rahman, Jumani, Akhter, Chisthi, \& Ajmal (2011) believed that teacher training program enable the class to achieve effective learning. Thus highlight the positive correlation between teacher training and students' learning process.

\section{CONCLUSION}

The learning process of mathematics subject in SD N Gunungsaren, SD N Kentungan, and SD N Semanu III is conducted in a studentcentered method, in which students are encouraged to actively get involved. However, each school possesses different strength. SD N Semanu III shows an advantage of LCD projector installment that used by the teacher optimally for learning. SD N Kentungan appears superior with parents' involvement by providing support facilities. While, SD N Gunungsaren is backed up by creative teachers as the result of teacher training program. From this research result, the keywords of learning success are availability of school facilities, parents' involvement, and teachers' creativity. It is recommended to every school all over the world to pay attention to those three factors so that students' mathematics achievement can be improved.

\section{REFERENCES}

Altschul, I. (2011). Parental involvement and the academic achievement of Mexican American youths: What kinds of involvement in youths' education matter most?. Social Work Research, 35(3), 159170. https://doi.org/10.1093/swr/35.3.159.

Anazifa, R. D., \& Djukri. (2017). Project-based learning and problem-based learning: are they effective to improve student's thinking skills? Jurnal Pendidikan IPA Indonesia, 6(2), 346-355. https://doi.org/10.15294/jpii.v6i2.11100

Apino, E., \& Retnawati, H. (2017). Developing instructional design to improve mathematical higher order thinking skills of students. Journal of Physics: 
Conference Series, 812, 1-7. https://doi.org/10.1088/1742-6596/755/1/011001

Bailey, L.B., Silvern, S.B., Brabham, E., \& Ross, M. (2004). The effect of interactive reading homework and parent involvement on children's inference responses. Early Childhood Education Journal, 32(3), 173178.

Baradaran, M., Khosravipour, B., Rafe, M., Moosavi, S.A., \& Roozbahani, M. (2015). Analyzing effect of teachers' creativity education on students academic achievement in secondary school. International Journal of Advanced Biological and Biomedical Research, 3(4), 326-331.

Chambers, P. (2008). Teaching mathematics: developing as a reflective secondary teacher. London: SAGE Publication Ltd.

Djidu, H., \& Jailani, J. (2017). Aktivitas pembelajaran matematika yang dapat melatih kemampuan berpikir tingkat tinggi siswa. PRISMA, Prosiding Seminar Nasional Matematika, 1(1), 312-321. Retrieved from https://journal.unnes.ac.id/sju/index.php/p risma/article/view/21614

Djidu, H., \& Jailani, J. (2018). Developing problem based calculus learning model. Jurnal Kependidikan: Penelitian Inovasi Pembelajaran, 2(1), 68-84. https://doi.org/10.21831/JK.V2I1.12689.

Ganyaupfu, E.M. (2013). Teaching methods and students' academic performace. International Journal of Humanities and Social Science Invention, 2(9), 29-35.

Gurney, P. (2007). Five factors for effective teaching. New Zealand Journal of Teachers' Work, 4(2), 89-98.

Harris, A. \& Goodall, J. (2008). Do parents know they matter? Engaging all parents in learning. Educational Research, 50(3), 277-289.

Haylock, D. \& Thangata, F. (2007). Key concepts in teaching primary mathematics. Los Angeles: Sage Publications.

Hewitt, D. \& Tarrant, S. (2015). Innovative teaching and learning in primary schools. Los Angeles: Sage Publications.

Ibe, E., Nworgu, L.N., \& Anyaegbunam, N. J. (2016). Influence of teachers' characteristic on academic achievement of secondary school biology students. British Journal of Science, 13(2), 33-44.

Jailani, J., Sugiman, S., \& Apino, E. (2017). Implementing the problem-based learning in order to improve the students' HOTS and characters. Jurnal Riset Pendidikan Matematika, 4(2), 247-259. https://doi.org/10.21831/jrpm.v4i2.17674

Jethro, O.O. \& Aina, F.F. (2012). Effect of parental involvement on the academic performance of student in elementary school. International Journal of Academic Research in Business and Social Sciences, 2(1), 196-202.

Kanold, T.D., Briars, D.J., \& Fennel, F. (2012). What principals need to know about teaching and learning mathematics. New York: Solution Tree Press.

Khursid, F. \& Ansari, U. (2012). Effect of innovative teaching strategies on students' performance. Global Journal of Human Social Science, 12(10), 47-53.

Laili, H. (2016). Keefektifan pembelajaran dengan pendekatan CTL dan PBL ditinjau dari motivasi dan prestasi belajar matematika. Pythagoras: Jurnal Pendidikan Matematika, 11(1), 25-34. Doi: 10.21831/pg.v11i1.9679

Limon, M.R. (2016). The effect of the adequcy of school facilities on student's performance and achievement in technology and livelihood education. Interntional Journal of Academic Research in Progressive Education and Development, 5(1), 45-58.

Miles, M.B., Huberman, A.M., \& Saldana, J. (2014). Qualitative data analysis: A methods sourcebook. California: Sage Publications.

Mo, Y. \& Singh, K. (2008). Parents' relationship and involvement: Effect on students' school engagement and performance. Research in Middle Level Education Online, 31(10), 1-11.

Murdiyani, N. (2013). Scaffolding to support better achievement in mathematics. Pythagoras: Jurnal Pendidikan Matematika, 8(1), 84-91. Retrieved from http://journal.uny.ac.id/index.php/pythago ras/article/view/8496

Mushtaq, I. \& Khan, S.N. (2012). Factors affecting students' academic performance. 
Global Journal of Management and Business Research, 12(9), 17-22.

National Research Council. (2001). Adding it up: Helping children learn mathematics. J. Kilpatrick, J. Swafford, and B. Findell (Eds.). Mathematics Learning Study Committee, Center for Education, Division of Behavioral and Social Sciences and Education. Washington, DC: National Academy Press.

Odeh. R.C., Oguche, A., \& Ivagher, E.D. (2015). Influence of school environment on academic achievement of students in secondary school in zone " $A$ " senatorial district of Benue State, Nigeria. International Journal of Recent Scientific Research, 6(7), 4914-4922.

Olaleye, F.O. (2011). Teacher characteristic as predictor of academic performance of students in secondary schools in Osun State - Nigeria. European Journal of Educational Studies, 3(3), 505-511.

Osguthorpe, R.D. (2008). On the reasons we want teachers of good disposition and moral character. Journal of Teacher Education, 59(4), 288-299.

Rahman, F., Jumani, N.B., Akhter, Y, Chisthi, S.H., \& Ajmal, M. (2011). Relationship between training of teachers and effectiveness teaching. International Journal of Business and Social Science, 2(4), 150-160.

Retnawati, H., Djidu, H., Kartianom, K., Apino, E., \& Anazifa, R. D. (2018). Teachers' knowledge about higher-order thinking skills and its learning strategy. Problem of Education in the 21st Century, 76(2), 215230. Retrieve from http://oaji.net/articles/2017/4571524597598.pdf

Retnawati, H., Kartowagiran, B., Hadi, S., \& Hidayati, K. (2011). Identifikasi kesulitan peserta didik dalam belajar matematika dan sains di Sekolah Dasar. Jurnal Kependidikan, 41(2), 162-174.

Riedesel, C.A., Schwartz, J.E., \& Clements, D.H. (1997). Teaching elementary school mathematics. Boston: Allyn and Bacon.

Sanjaya, W. (2013). Strategi pembelajaran berorientasi standar proses pendidikan. Jakarta: Prenada.

Singh, S.P., Malik, S., \& Singh, P. (2016). Factors affecting academic performance of students. Indian Journal of Research, 5(4), 176-178

Suleman, Q. \& Hussain, I. (2014). Effects of classroom physical environment on the academic achievement scores of secondary school students in Kohat Division, Pakistan. International Journal of Learning \& Development, 4(1), 71-82.

Thompson, K.M., Gillis, T.J., Fairman, J., \& Mason, C.A. (2014). Effective strategies for engaging parents in students' learning to support achievement. Orono, Maine: University of Maine, Center for Research and Evaluation/Maine Education Policy Research Institute. [Technical report for Maine State Legislature].

Topor, D.R., Keane, S.P., Shelton, T.L., \& Calkins, S.D. (2010). Parent involvement and student academic performance: A multiple mediational analysis. Journal of Prevention \& Intervention in the Community, 38(3), 183-197. Doi: 10.1080/10852352.2010.486297

Widiastuti, W., \& Santosa, R. (2014). Pengaruh metode inkuiri terhadap ketercapaian kompetensi dasar, rasa ingin tahu, dan kemampuan penalaran matematis. Pythagoras: Jurnal Pendidikan Matematika, 9(2), 196-204. Retrieved from http://journal.uny.ac.id/index.php/pythagoras/article/view/9080 